\title{
Quantitative DNA methylation analysis of paired box gene 1 and LIM homeobox transcription factor $1 \alpha$ genes in cervical cancer
}

\author{
LING XU*, JUN XU, ZHENG HU*, BAOHUA YANG, LIFENG WANG, \\ XIAO LIN, ZIYIN XIA, ZHILING ZHANG and YUNHENG ZHU \\ Department of Obstetrics and Gynecology, Minhang Hospital, Fudan University, Shanghai 201199, P.R. China
}

Received October 25, 2016; Accepted November 2, 2017

DOI: $10.3892 / \mathrm{ol} .2018 .7872$

\begin{abstract}
DNA methylation is associated with tumorigenesis and may act as a potential biomarker for detecting cervical cancer. The aim of the present study was to explore the methylation status of the paired box gene 1 (PAX1) and the LIM homeobox transcription factor $1 \alpha$ (LMX1A) gene in a spectrum of cervical lesions in an Eastern Chinese population. This single-center study involved 121 patients who were divided into normal cervix $(\mathrm{NC} ; \mathrm{n}=28)$, low-grade squamous intraepithelial lesion (LSIL; $n=32$ ), high-grade squamous intraepithelial lesion (HSIL; $n=34$ ) and cervical squamous cell carcinoma (CSCC; $n=27$ ) groups, according to biopsy results. Following extraction and modification of the DNA, quantitative assessment of the PAX1 and LMX1A genes in exfoliated cells was performed using pyrosequencing analysis. Receiver operating characteristic (ROC) curves were generated to calculate the sensitivity and specificity of each parameter and cut-off values of the percentage of methylation reference (PMR) for differentiation diagnosis. Analysis of variance was used to identify differences among groups. The PMR of the two genes was significantly higher in the HSIL and CSCC groups compared with that in the NC and LSIL groups $(\mathrm{P}<0.001)$. ROC curve analysis demonstrated that the sensitivity, specificity and accuracy for detection of CSCC were 0.790, 0.837 and 0.809, respectively, using PAX1; and $0.633,0.357$ and 0.893 , respectively, using LMX1A. These results indicated that quantitative PAX1 methylation demonstrates potential for cervical cancer screening, while further investigation is required to determine the potential of LMX1A methylation.
\end{abstract}

Correspondence to: Dr Jun $\mathrm{Xu}$, Department of Obstetrics and Gynecology, Minhang Hospital, Fudan University, 170 Xinsong Road, Shanghai 201199, P.R. China

E-mail: edelweiss76@163.com

${ }^{*}$ Contributed equally

Key words: cervical cancer, paired box gene 1, LIM homeobox transcription factor $1 \alpha$, methylation, human papillomavirus

\section{Introduction}

Cervical cancer (CC) is one of the most common types of gynecological malignant tumor (1). The main histological type is cervical squamous cell carcinoma (CSCC), which accounts for $75-80 \%$ of cases; adenocarcinoma accounts for $10-15 \%$ and other histological subtypes represent $10-15 \%(2,3)$. Although there has been a declining trend over the past few decades, CC remains a major health problem for Chinese women, particularly for those living in rural areas (4). CC originating from cervical intraepithelial neoplasia (CIN) is often caused by high risk-human papilloma virus (HR-HPV) infection (5). CIN is a group of cervical lesions that are associated with $\mathrm{CC}$ and are divided into three grades (I, II and III) $(6,7)$. The majority of low-grade CIN cases naturally subside, but high-grade lesions continue to develop and break through the sub-epithelial basement membrane, at which point they are referred to as cervical invasive carcinoma $(7,8)$. Histology is currently the basis for the diagnosis and classification of CIN (6).

The early detection of lesions by screening remains the primary prevention method for CC. CIN often occurs in women aged 25-35 years (6) and the highest incidence of CC occurs at $\sim 47$ years of age (9), suggesting a slow evolution from precancerous lesions to CC. Additionally, HPV vaccination for the prevention of $\mathrm{CC}$ is offered in numerous regions around the world, but it is not widely applied in a number of countries, including mainland China $(4,10)$. Finally, since the 1950s, due to the widespread use of cervical cytology screening, cervical precancerous and cancerous lesions may be identified and treated early, resulting in a significant decrease in the incidence, and mortality of CC $(11,12)$. Therefore, early detection of lesions by screening is effective for $\mathrm{CC}$ prevention. In addition, screening and detection of high-grade CIN lesions and early $\mathrm{CC}$, and providing timely treatments may represent effective measures for increasing the rate of cure in these diseases.

The Papanicolaou (Pap) test is currently the main screening method for cervical precancerous changes and CC $(13,14)$. However, the sensitivity of the Pap test varies greatly, ranging between $30-87 \%$, and sometimes being as low as $20 \%(14,15)$. In addition, the infrastructure used for Pap screening is expensive and is difficult to implement in developing countries (16). Although the thin-layer liquid-based cervical cytology technique has improved recently, the sensitivity of the test 
has led to an important number of equivocal cytological results that require confirmation $(9,17)$. Due to the fact that persistent HR-HPV infection is a well-established cause of cervical neoplasia, HPV nucleotide detection is an attractive method for the detection of cervical lesions (18-20), but only a small proportion of the HR-HPV infected individuals exhibit cervical lesions, and the HPV test demonstrates limited specificity in diagnosing CC, particularly in young women $(21,22)$.

DNA methylation involves intensive epigenetic modifications that serve important roles in gene expression or silencing in normal mammalian cells $(10,23)$. DNA methylation-induced alteration of C-phosphate- $\mathrm{G}(\mathrm{CpG})$ islands in tumor suppressor gene promoter regions is often observed in human cancer (24-27). It is currently acknowledged that hyper- or hypo-methylation of tumor suppressor gene promoter regions may contribute to cell transformation and thus, that the DNA methylation status is a promising biomarker for the detection of cancer (28). For $\mathrm{CC}, \mathrm{HPV}$ viral DNA methylation acts as a potential biomarker for early cancer detection. For example, methylation of multiple genes, including paired box gene 1 (PAX1) (29), LIM homeobox transcription factor $1 \alpha$ (LMX1A), NK6 transcription factor-related locus 1 (30), SRY-box 1, Wilms tumor 1 and one cut homeobox 1 (31), have demonstrated varying degrees of sensitivity, specificity, and accuracy for the detection of CIN grades III and above. Nevertheless, the diagnostic accuracy of these genes requires further evaluation.

The purpose of the present study was to explore the diagnostic accuracy of the quantitative methylation analysis of two genes, PAX1 and LMX1A, in a full spectrum of cervical lesions in an Eastern Chinese population.

\section{Patients and methods}

Study design. This single-center prospective clinical study was approved by the Ethics Committee of the Central Hospital of Minhang District (Shanghai, China). Between July 2013 and September 2014, 121 subjects with cervical cancer were recruited, and tested for PAX1 and LMX1A methylation genes prior to undergoing pathological examination at the gynecological department of the Central Hospital of Minhang District. The tissue histopathology of cervical tissue was used for diagnosis and the diagnostic accuracy of CIN and CC was assessed using the gene methylation test.

Patients. The study recruited adult women from a population undergoing routine health examination and those clinically diagnosed with CC (age range 21-57; mean age, 37.15 \pm 8.6 ). Potential participants were screened for eligibility using a structured questionnaire and detailed clinical assessment. The inclusion criteria were as follows: i) Patients and healthy women receiving cytological examination, using the thin-layer liquid-based technique (32), of the cervical exfoliated cells and quantitative detection of HR-HPV DNA; ii) women aged 21-57 years with a history of sexual activity; and iii) women who provided written informed consent to participate in the study. The exclusion criteria were: i) Refusal to undergo further colposcopy, cervical biopsy or cervical loop electrosurgical excision and hysterectomy; ii) history of other malignant tumors; iii) treatment for other cervical diseases during the study; or iv) histopathological diagnosis of cervical adenocarcinoma.
Examination and grouping. All the participants received a histological examination and underwent a colposcopic cervical biopsy by a trained medical doctor. Cervical exfoliated cell specimens were taken by a nurse using a Cervex-Brush (Rovers Medical Devices, Oss, The Netherlands) and smeared onto a slide for cytological examination. The hospital team comprised 10 pathologists, each with $>20$ years of experience. Biopsied tissues were fixed in $10 \%$ neutral-buffered formalin for $24 \mathrm{~h}$ at $37^{\circ} \mathrm{C}$. Paraffin-embedded sections (4- $\mu \mathrm{m}$ thick) were cut for hematoxylin and eosin staining $\left(5-15 \mathrm{~min}\right.$ at $\left.37^{\circ} \mathrm{C}\right)$ and immunohistochemistry. To generate frozen $\left(-20^{\circ} \mathrm{C}\right)$ sections, fresh tissues were embedded in Tissue-Tek O.C.T compound (Sakura Finetek Europe B.V., Flemingweg, The Netherlands) immediately after removal. Frozen sections $(7 \mu \mathrm{m})$ were used for immunofloresence.

The participants were then grouped according to the tissue biopsy results as NC (normal cervix), LSIL (low-grade squamous intraepithelial lesion), HSIL (high-grade squamous intraepithelial lesion) or CSCC (cervical squamous cell carcinoma). Since $60 \%$ of the grade I CIN lesions naturally fade and require no treatment (only follow-up if the disease does not progress within 2 years), CIN1 lesions were classified as LSIL. Approximately $20 \%$ of CIN2 lesions progress to CIN3 and $5 \%$ of these lesions eventually become invasive cancer; therefore, CIN2 and CIN3 lesions were classified as HSIL (33).

Immunohistochemistry. For immunohistochemistry, all antibodies and reagents were purchased from Fuzhou Maixin Biotechnology Development Co., Ltd. (Fuzhou, China) and immunohistochemistry was performed according to the UltraSensitive $^{\mathrm{TM}}$ SP (Mouse/Rabbit) IHC kit (cat no. KIT-9710; Fuzhou Maixin Biotechnology Development Co., Ltd.) manufacturer's protocol. The first step was to bake the paraffin section at $60^{\circ} \mathrm{C}$ for $2 \mathrm{~h}$, followed by xylene dewaxing and alcohol hydration for $3 \mathrm{~h}$ at $60^{\circ} \mathrm{C}$, following these procedures: xylene I for $60 \mathrm{~min}$, xylene II for $30 \mathrm{~min}, 100 \%$ alcohol for $30 \mathrm{~min}, 95 \%$ alcohol for $15 \mathrm{~min}, 75 \%$ alcohol for $15 \mathrm{~min}, 50 \%$ alcohol for $15 \mathrm{~min}$ and washing with distilled water for $15 \mathrm{~min}$. In order to block inactivated endogenous peroxidase, cells were incubated with $3 \% \mathrm{H}_{2} \mathrm{O}_{2}$ at $37^{\circ} \mathrm{C}$ for $10 \mathrm{~min}$, followed by washing with phosphate-buffered saline (PBS) three times for $5 \mathrm{~min}$. Then, for antigen repair, $0.01 \mathrm{M}$ citric acid tissue antigen repair solution ( $\mathrm{pH}$ 6.0) was used for boiling (at $95^{\circ} \mathrm{C}$, for 15 to $20 \mathrm{~min}$ ), and then the cells were allowed to cool naturally for $20 \mathrm{~min}$. Then, the cylinder was rinsed with cold water and cooling was accelerated to room temperature, followed by washing with PBS three times for $5 \mathrm{~min}$. Normal sheep serum was enclosed with the cells and incubated at $37^{\circ} \mathrm{C}$ for $20 \mathrm{~min}$, followed by removing the normal sheep serum without washing. The primary antibodies p16 (cat no. MAB-0673; Fuzhou Maixin Biotechnology Development Co., Ltd.) at 1:100 dilution and ki67 (cat no. MAB-0672; Fuzhou Maixin Biotechnology Development Co., Ltd) at 1:200 dilution were added respectively and refrigerated at $4^{\circ} \mathrm{C}$ overnight, and washed with PBS three times for 5 min (with PBS buffer used as a negative control). A total of $50 \mu 1$ biotinylated goat anti-mouse/rabbit IgG [Buffer C from the UltraSensitive SP (Mouse/Rabbit) IHC kit; cat no. KIT-9710] was performed at $37^{\circ} \mathrm{C}$ for a 30 -min incubation, followed by washing with PBS three times for $5 \mathrm{~min}$. A total of $50 \mu \mathrm{l}$ horseradish peroxidase-labeled streptomycin avidin working liquid 
[Buffer D from the UltraSensitive SP (Mouse/Rabbit) IHC kit, product number: KIT-9710], for the specific recognition of the biotin-labeled secondary antibody, was then added for a 30 -min incubation at $37^{\circ} \mathrm{C}$, followed by washing with PBS three times for $5 \mathrm{~min}$. This method ensures a higher sensitivity (34). Then 3,3'-Diaminobenzidine $/ \mathrm{H}_{2} \mathrm{O}_{2}$ reaction staining at $37^{\circ} \mathrm{C}$ for 3-10 min was performed. After washing with the tap water for 5 times within $15 \mathrm{~min}$, the haematin was used for re-dying at $37^{\circ} \mathrm{C}$ for $1 \mathrm{~min}$, followed by normal alcohol dehydration at $37^{\circ} \mathrm{C}$ for $5-10 \mathrm{~min}$, treated with xylene for $4-6 \mathrm{~min}$ at $37^{\circ} \mathrm{C}$ to increase the transmittance of the specimen, and the specimen was covered with a square coverslip by adding the neutral gum to seal, followed by drying naturally at room temperature for later observation.

Immunofluorescence. Frozen sections ( $7 \mu \mathrm{m}$ thick) were fixed with $2 \%$ paraformaldehyde in PBS at room temperature for 10 min followed by extraction using $0.5 \%$ Triton X-100 in PBS for $5 \mathrm{~min}$, at room temperature. Blocking was then performed using 0.01 M PBS (pH 7.4) containing $10 \%$ normal goat serum and $0.3 \%$ Trixton $\mathrm{X}-100$ for $1 \mathrm{~h}$ at room temperature, followed by the addition of the primary antibodies as follows: Human Anti-CDKN2A mouse monoclonal antibody (cat no. D199930; Sangon Biotech Co., Ltd., Shanghai, China) at a 1:100 dilution, diluted with with $0.01 \mathrm{M}$ PBS (pH 7.4) containing 1\% BSA and $0.3 \%$ Triton X-100 and human Ki-67 (D3B5) Rabbit mAb (Alexa Fluor ${ }^{\circledR} 647$ Conjugate; cat no. 12075; Cell Signaling Technology) at a 1:50 dilution, diluted with $0.01 \mathrm{M} \mathrm{PBS}(\mathrm{pH} 7.4)$ containing $1 \%$ BSA and $0.3 \%$ Triton $\mathrm{X}-100$, and incubated with these antibodies at $4{ }^{\circ} \mathrm{C}$ overnight. This was followed by washing with PBS three times for $10 \mathrm{~min}$ in the dark. Then, incubation with the secondary antibody FITC-conjugated Donkey Anti-Mouse IgG (cat no. D110081; Sangon Biotech Co., Ltd.) was performed at a 1:100 dilution, diluted with $0.01 \mathrm{M}$ PBS (pH 7.4) containing $1 \%$ BSA and $0.3 \%$ Triton X-100 and incubated for $1 \mathrm{~h}$ at room temperature, followed by washing with PBS three times for $15 \mathrm{~min}$. Fluorescence microscopy was performed following sealing. DNA was visualized using $\sim 1.5 \mathrm{~g} / \mathrm{ml}$ Hoechst 33342 (Sigma-Aldrich; Merck KGaA, Darmstadt, Germany). Fluorescence microscopy was performed using a 60x Plan Apo (NA 1.40) oil immersion objective lens and a Nikon TE2000-U inverted microscope equipped with a SPOT-RT CCD system.

DNA methylation: Cervical DNA extraction, bisulfite treatment and modification. DNA was extracted from the obtained exfoliated cells using an Omniscript RT kit (Qiagen, Inc., Valencia, CA, USA), according to the manufacturer's protocols. The extracted DNA was subjected to bisulfite treatment, DNA was tested for purity and concentration using Nanodrop ${ }^{\text {TM }} 2000$ (Thermo Fisher Scientific, Inc., Waltham, MA, USA). 500 ng DNA was placed into a polymerase chain reaction (PCR) tube, followed by denaturation at $95^{\circ} \mathrm{C}$ for $5 \mathrm{~min}$, and refolding at $60^{\circ} \mathrm{C}$ for three rounds (for 25,85 and then $175 \mathrm{~min}$ ) of reciprocation on a PCR instrument using an EpiTect Bisulfite kit (Qiagen GmbH, Hilden, Germany). The reaction solution was transferred to a $1.5 \mathrm{ml}$ Eppendorf tube and was then treated with Buffer BL, Buffer BW and Buffer BD (part of the EpiTect Bisulfite kit), respectively. Subsequently, the Eppendorf tube was centrifuged at $95^{\circ} \mathrm{C}$ for $1 \mathrm{~min}$ at a speed of $14,100 \mathrm{x} \mathrm{g}$ in the EpiTect spin columns (Qiagen $\mathrm{GmbH}$ ), and finally the sulfite-treated product was eluted with $20 \mu \mathrm{l}$ Buffer EB, according to the manufacturer's protocols. Polymerase chain reaction (PCR) was used to amplify the target fragments. The primer sequences used were as follows: PCR primer forward, 5'-TATTTTGGGTTTGGGGTCGC-3' and reverse, 5'-CCC GAAAACCGAAAACCG-3'; sequencing primer, 5'-TTT TTGTTTTAGAGAGGTTAGTAAT-3'. The primers were all synthesized by Sangon Biotech Co., Ltd. (Shanghai, China). PCR was performed as follows: i) Initial denaturation at $95^{\circ} \mathrm{C}$ for $5 \mathrm{~min}$; ii) denaturation at $94^{\circ} \mathrm{C}$ for $30 \mathrm{sec}$, annealing at $64^{\circ} \mathrm{C}$ for $30 \mathrm{sec}$ and elongation at $72^{\circ} \mathrm{C}$ for $40 \mathrm{sec}$, for a total of 40 cycles; and iii) final elongation at $72^{\circ} \mathrm{C}$ for $10 \mathrm{~min}$. The products were separated using a $2 \%$ agarose gel.

Quantitative bisulfite pyrosequencing analysis. Quantitative detection of methylation was performed for the suppressor genes in the cervical tissues. According to the methylation sequencing kit (Qiagen GmbH, Hilden, Germany), a reaction solution was prepared, containing $0.1 \mathrm{~mol} / 1$ Tris Ac buffer $(\mathrm{pH} 7.7$ ), $2 \mathrm{mmol} / \mathrm{l}$ EDTA, $10 \mathrm{mmol} / \mathrm{l} \mathrm{Mg}(\mathrm{Ac})$ 2, 0.1\% bovine serum albumin, $1 \mathrm{mmol} / 1$ dithiothreitol, $3 \mu \mathrm{mol} / 1$ 5'-phosphorylated adenosine sulfate, $0.4 \mu \mathrm{g} / \mathrm{l}$ polyvidone, $0.4 \mathrm{mmol} / \mathrm{l} \mathrm{D}$ luciferin, 2x10-4 U/1 ATP sulfurylase, $2 \times 10^{-3} \mathrm{U} / 1$ dual phosphatase ATP and $18 \times 10^{-3} \mathrm{U} / 1$ Klenow DNA polymerase (without exonuclease activity and containing $14.6 \mathrm{mg} / \mathrm{l}$ luciferase; New England Biolabs, Ipswich, MA, USA). Next, the methylation of the samples was measured and the average value was calculated based on the degree of methylation of the nine loci (according to the criteria (35) of methylation grouping that represents the degree of methylation for each sample).

Statistical analysis. One-way analysis of variance with Tukey's test used for post hoc analysis was used to evaluate differences in the percentage of methylation reference (PMR) among the groups. Continuous data are presented as the mean \pm standard deviation. Categorical data were analyzed using the $\chi^{2}$ test. Receiver operating characteristic (ROC) curves were generated to confirm the accuracy of diagnosis for each gene, and the sensitivity and specificity were calculated. $\mathrm{P}<0.05$ was considered to indicate a statistically significant difference. Statistical analysis was performed using SPSS 20.0 (IBM Corp., Armonk, NY, USA).

\section{Results}

The patient distribution was $n=28$ for the NC group, $n=32$ for the LSIL, $n=34$ for the HSIL and $n=27$ for the CSCC group (Table I). The mean patient age increased with disease severity $(\mathrm{P}<0.006)$. The proportion of HPV-negative samples was significantly lower in the NC group compared with in the CIN and $\mathrm{CC}$ groups $(\mathrm{P}<0.05)$. The proportions of positive PAX1 and LMX1A methylated genes were higher in cervical tissues and exfoliated cells in the HSIL and CSCC groups compared with those in the LSIL and NC groups, but no significant difference was observed between the NC and LSIL groups (Table I; Fig. 1).

The methylation levels of PAX1 and LMX1A were quantitatively detected by pyrosequencing. An example of the PAX1 pyrosequencing results of a single specimen was demonstrated in Fig. 2. 
Table I. Characteristics of participants and gene methylation.

\begin{tabular}{|c|c|c|c|c|c|}
\hline Variable & $\mathrm{NC}(\mathrm{n}=28)$ & LSIL (n=32) & HSIL (n=34) & $\operatorname{CSCC}(n=27)$ & P-value \\
\hline Age, years & $36.2 \pm 7.7$ & $28.3 \pm 7.6$ & $39.7 \pm 10.5$ & $44.4 \pm 8.8$ & 0.006 \\
\hline HPV-negative & 18 & 6 & 3 & 2 & $<0.001$ \\
\hline High-risk HPV & 10 & 26 & 31 & 25 & \\
\hline HPV DNA & $89.85 \pm 95.77$ & $480.23 \pm 702.79$ & $630.28 \pm 623.75$ & $1650.80 \pm 4595.88$ & 0.23 \\
\hline PAX1 in tissue & $4.92 \pm 4.45$ & $5.55 \pm 5.05$ & $10.21 \pm 14.39$ & $41.97 \pm 23.02$ & $<0.001$ \\
\hline PAX1 in exfoliated cell & $4.57 \pm 2.43$ & $3.38 \pm 2.36$ & $13.64 \pm 13.35$ & $26.38 \pm 18.53$ & $<0.001$ \\
\hline LMX1A in tissue & $4.53 \pm 3.76$ & $5.05 \pm 3.06$ & $4.70 \pm 5.12$ & $14.36 \pm 18.31$ & $<0.001$ \\
\hline LMX1A in exfoliated cell & $2.15 \pm 1.26$ & $3.35 \pm 1.89$ & $5.66 \pm 2.60$ & $9.18 \pm 12.1$ & $<0.001$ \\
\hline $\mathrm{TCT}, \mathrm{n}$ & & & & & $<0.001$ \\
\hline Normal (NC) & 20 & 7 & 4 & 5 & \\
\hline Low (CIN1) & 1 & 6 & 2 & 1 & \\
\hline High (CIN2-3) & 1 & 1 & 17 & 18 & \\
\hline ASC-US & 6 & 18 & 11 & 1 & \\
\hline CSCC & 0 & 0 & 0 & 2 & \\
\hline
\end{tabular}

Values are in n, unless otherwise stated. NC, normal cervix; LSIL, low-grade squamous intraepithelial lesion; HSIL, high-grade squamous intraepithelial lesion; CSCC, cervical squamous-cell carcinoma; HPV, human papilloma virus; PAX1, paired box gene 1; LMX1A, LIM homeobox transcription factor $1 \alpha$; LMX2A, LIM homeobox transcription factor $2 \alpha$; TCT, thin-layer liquid-based cervical cytology; CIN, cervical intraepithelial neoplasia; ASC-US, atypical squamous cells of undetermined significance.

A

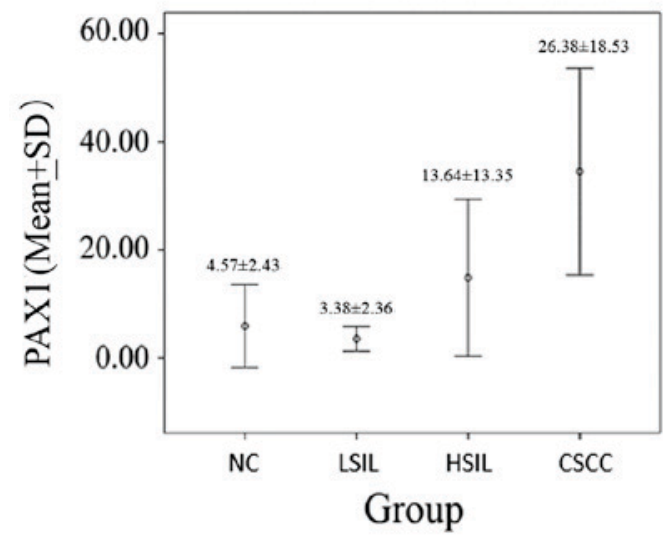

B

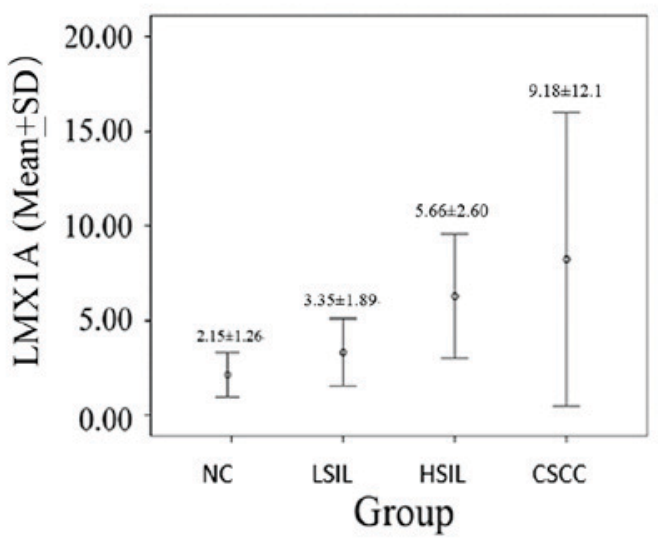

Figure 1. Quantitative comparison of methylation of (A) PAX1 and (B) LMX1A in the cervical exfoliated cells among different groups. PAX1, paired box gene 1; LMX1A, LIM homeobox transcription factor $1 \alpha$; SD, standard deviation. NC, negative control; LSIL, low-grade squamous intraepithelial lesion; HSIL, high-grade squamous intraepithelial lesion; CSCC, cervical squamous-cell carcinoma.

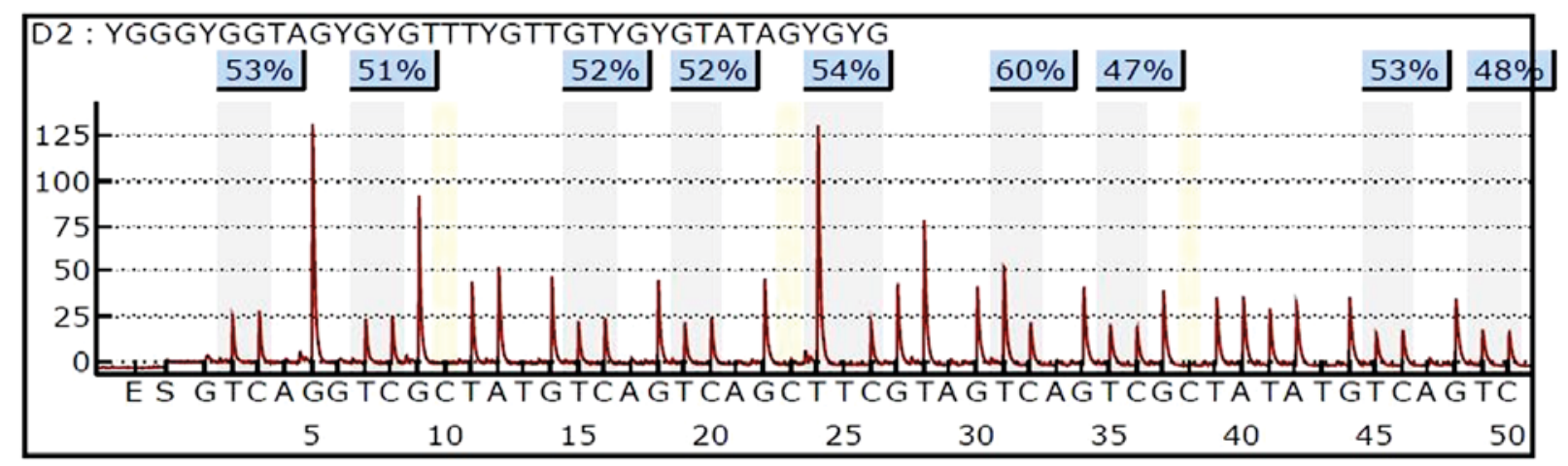

Figure 2. An example of the PAX1, paired box gene 1 pyrosequencing results of a single specimen. The gray areas are the 9 CpG sites, and the methylation percentage of each $\mathrm{CpG}$ site was automatically displayed at the top of the $\mathrm{CpG}$ site. 

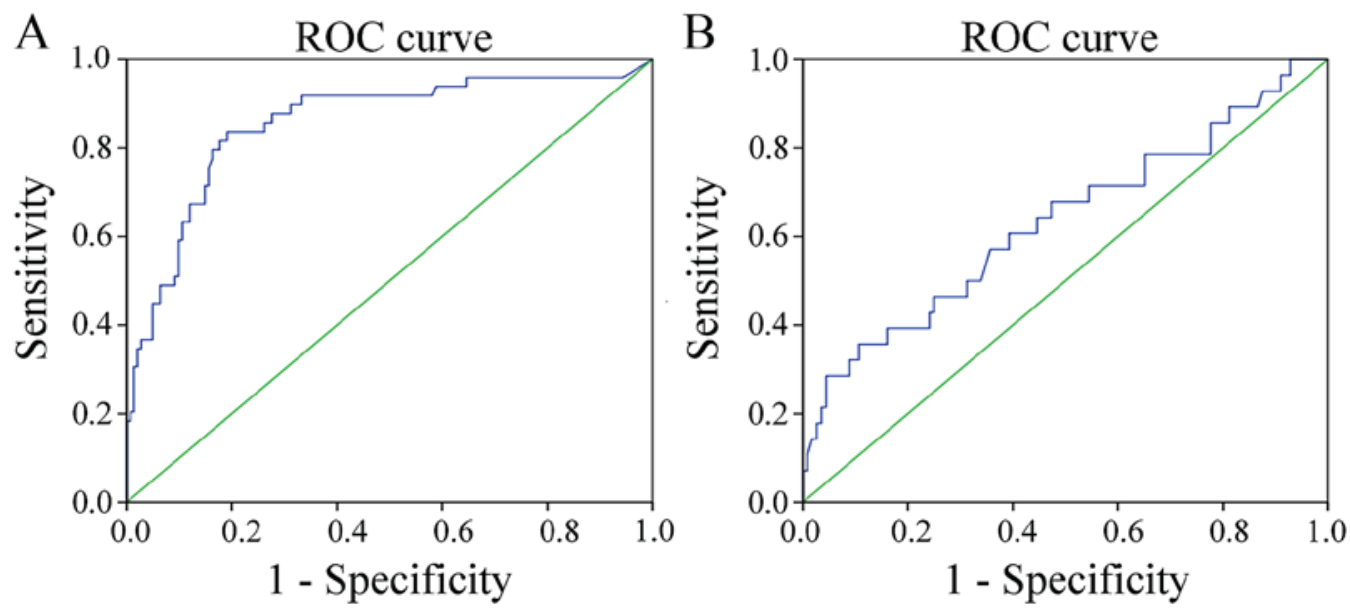

Figure 3. ROC curves of the diagnostic threshold of quantitative methylation of (A) paired box gene 1 and (B) LIM homeobox transcription factor $1 \alpha$ in the exfoliated cells. Cervical squamous-cell carcinoma vs. high-grade squamous intraepithelial lesion+low-grade squamous intraepithelial lesion+negative control. ROC, receiver operating characteristic; CSCC, cervical squamous-cell carcinoma.
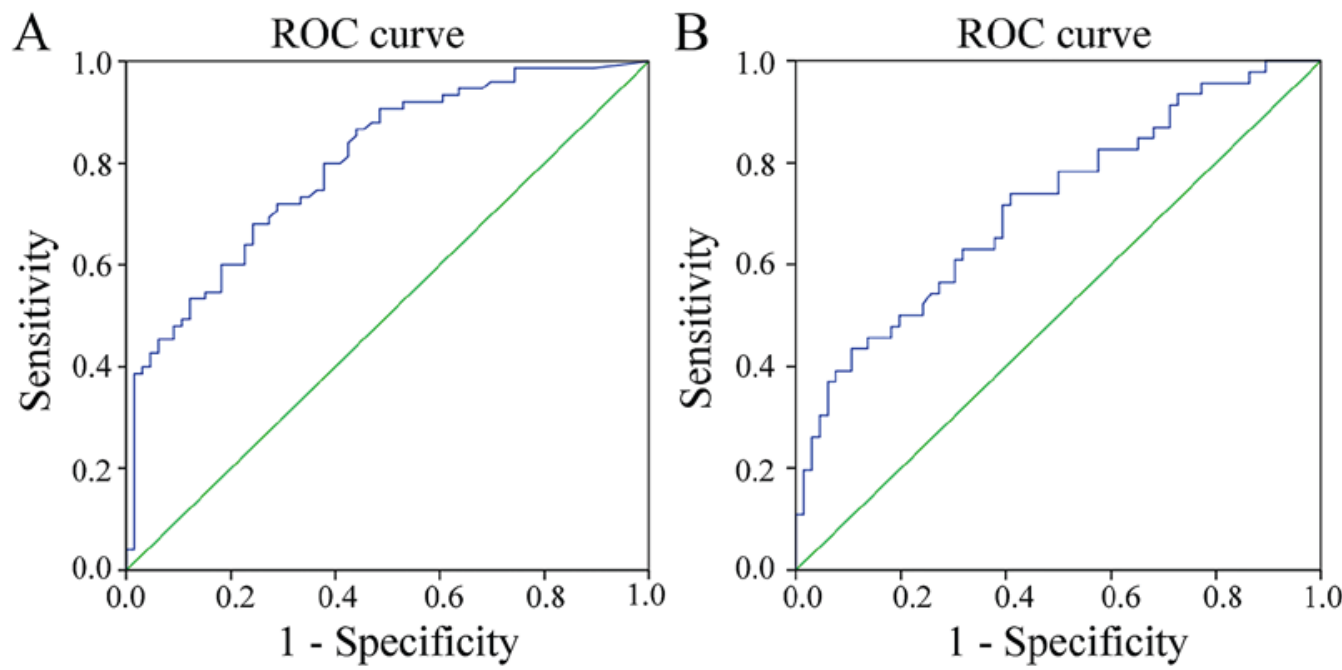

Figure 4. ROC curves of the diagnostic threshold of quantitative methylation of (A) paired box gene 1 and (B) LIM homeobox transcription factor $1 \alpha$ in the exfoliated cells. high-grade squamous intraepithelial lesion vs. low-grade squamous intraepithelial lesion+negative control. ROC, receiver operating characteristic.

To evaluate the diagnostic potential of the two genes, respective ROC curves were produced (Figs. 3 and 4). Methylated PAX1 demonstrated a greater ability to detect cancer compared with LMX1A (the sensitivities at the cut-off points were 0.837 and 0.357 , respectively; $\mathrm{P}<0.001)$, although the specificity values for the two genes were similar and high ( 0.809 and 0.893 , respectively; Table II). In addition, when comparing the ability to distinguish HSIL lesions from normal tissues and LSIL, the sensitivities at the cut-off values were similar, but not high (0.680 and 0.739 , respectively), while the specificities of the two genes differed significantly ( 0.758 vs. 0.591; $\mathrm{P}<0.001$; Table III).

\section{Discussion}

DNA methylation serves an important role in the regulation of gene expression or silencing in normal mammalian cells and has been proposed as a potential biomarker for the detection of cervical cancer $(10,23)$. DNA methylation-induced alteration of $\mathrm{CpG}$ islands in the tumor suppressor gene promoter regions are often observed in human cancer. The results of the present study revealed that the PMR of the two genes were significantly higher in the HSIL and CSCC groups compared with those in the NC, and LSIL groups. ROC curve analysis demonstrated that the sensitivity, specificity and accuracy for detecting CSCC of 0.790, 0.837 and 0.809 , respectively using LMX1A and $0.633,0.357$ and 0.893 , respectively using PAX1. Previous studies focused on detecting cervical cancer were hindered by inconsistent results of quantitative DNA methylation analysis, and moderate sensitivities and specificities using the available genes $(10,23)$.

Genes of the paired box (PAX) family serve important roles in embryonic development and organogenesis, and may be expressed persistently in stem cells and mature cells $(36,37)$. Specific PAX proteins are able to maintain stem cell properties, and are involved in the development and progression of solid tumors and hematologic cancer (38). As a downstream product of the gene, the PAX protein may be 
Table II. Sensitivity and specificity of PAX1 and LMX1A for distinguishing CSCC from HSIL, LSIL and NC (CSCC vs. HSIL+LSIL+NC).

\begin{tabular}{lccccrr}
\hline Gene & Cut-off & AUC & Sensitivity, $\%$ & Specificity, $\%$ & P-value & OR (95\% CI) \\
\hline PAX1 & 11.78 & 0.790 & 0.837 & 0.809 & $<0.001$ & $0.788-0.923$ \\
LMX1A & 7.185 & 0.633 & 0.357 & 0.893 & 0.029 & $0.508-0.758$ \\
\hline
\end{tabular}

CSCC, cervical squamous-cell carcinoma; HSIL, high-grade squamous intraepithelial lesion; NC, normal cervix; LSIL, low grade squamous intraepithelial lesion; AUC, area under the curve; OR, odds ratio; CI, confidence interval; PAX1, paired box gene 1; LMX1A, LIM homeobox transcription factor $1 \alpha$.

Table III. Sensitivity and specificity of PAX1 and LMX1A for distinguishing HSIL from LSIL+NC (HSIL vs. LSIL+NC).

\begin{tabular}{lccccrr}
\hline Gene & Cut-off & AUC & Sensitivity, $\%$ & Specificity, \% & P-value & OR (95\% CI) \\
\hline PAX1 & 5.405 & 0.799 & 0.680 & 0.758 & $<0.001$ & $0.727-0.871$ \\
LMX1A & 4.730 & 0.716 & 0.739 & 0.591 & $<0.001$ & $0.619-0.813$ \\
\hline
\end{tabular}

PAX1, paired box gene 1; LMX1A, LIM homeobox transcription factor $1 \alpha$; HSIL, high-grade squamous intraepithelial lesion; LSIL, low grade squamous intraepithelial lesion; NC, normal cervix; AUC, area under the curve; OR, odds ratio; CI, confidence interval.

expressed in tissue-specific stem cells (39). Previous studies have suggested that the anti-apoptotic function of PAX proteins may encourage tumor cells to continuously grow without undergoing apoptosis $(38,40)$. In breast cancer cells, PAX2 and estrogen receptor complexes regulate the expression of human epidermal growth factor 2 , which determines the response of tumor cells to tamoxifen (41). PAX3 and PAX7, as well as forkhead box protein O1, participate in rhabdomyosarcoma formation through chromosomal rearrangement $(42,43)$. In hepatocellular carcinoma, PAX5 inhibits tumor formation by mediating P53-associated signaling pathways (44). However, to the best of our knowledge, there is no current literature regarding the mechanisms of the PAX1 protein in malignant tumor development.

PAX1, as a member of the PAX family, serves an important regulatory role in the early development of an embryo, and is involved in the formation of bone, thymus and parathyroid glands $(38,45,46)$. Inactivation of PAX1 has been observed in patients with $\mathrm{CC}$ and is considered to be associated with the methylation of the promoter region $(47,48)$. In a hospital-based study on CC detection, Huang et al (49) observed that the quantitative measurement of PAX1 hypermethylation in cervical samples was highly sensitive and more specific compared with the Hybrid Capture 2 HPV test ( 0 vs. $5.9 \%$ in normal tissue). In the past, the study of PAX1 gene methylation in the cervix was found to be used for the differential diagnosis of invasive carcinoma (50). In the present study, the pyrosequencing quantitative methylation method confirmed the methylation analysis levels of PAX1, which identified CSCC or HSIL to a certain degree, as the AUCs were 0.790 (95\% CI, 0.788-0.923) and 0.799 (95\% CI, 0.727-0.871), respectively. When PAX1 methylation was detected for differentiating CSCC, the sensitivity and specificity were 0.837 and 0.809 , respectively. However, these indices decreased to 0.680 and 0.758 when HSIL was screened for. These data revealed that the detection of PAX1 methylation has clinical diagnostic value in differentiating invasive $\mathrm{CC}$, but may not be sufficient alone in screening for HSIL. A number of studies have indicated the potential value of PAX1 for the screening and detection of CC $(49,51,52)$, in line with the findings of the present study, but the association between PAX1 and tumors requires further investigation. The present study used methylation-specific PCR to demonstrate that the PAX1 gene is abnormally methylated in cervical cancer specimens, with methylation rates as high as $87.5 \%$, which is significantly different to those in normal cervical tissues and cervical precancerous lesions (49). Furthermore, the diagnostic sensitivity was twice that of the HPV-HC2 assay (53).

LMX1A is an important homeobox transcription factor in the process of cell development; it binds to AT-rich sequences in the insulin promoter and stimulates the transcription of insulin (54). In a previous study, LMX1A methylation testing demonstrated great potential for cervical lesion screening with a sensitivity, specificity and accuracy of $0.77,0.88$ and 0.90 , respectively (30). In the present study, the pyrosequencing method was used to confirm the methylation of the LMX1A gene in cervical epithelial malignant transformation, but it was hardly methylated in LSIL. Therefore, LMX1A methylation in cervical tissue detection may provide valuable information regarding the differentiation of invasive cancer, HSIL and LSIL. ROC analysis revealed a sensitivity and specificity of 0.357 and 0.893 , respectively, for CSCC; while the specificity for HSIL was 0.591 . These unsatisfactory data indicated that it may be necessary to combine other detection methods to improve accuracy. LMX1A methylation is dysregulated in gastric, bladder, breast, ovarian and pancreatic cancer (55-58). A study on various types of cancer may provide useful insights into the involvement of LMX1A methylation in tumorigenesis.

The present study has certain limitations. In addition to the small sample size, there was no combined analysis of the 
two genes or combined analysis of either gene using another test, as the preliminary results suggested that combined examination of multiple indices may be a feasible approach to improving the diagnostic accuracy of differentiating cervical lesions. In addition, the association between the two gene methylation statuses and disease prognosis was not analyzed due to problems at follow-up. Further multicenter studies, with larger sample sizes and strictly designed diagnostic criteria are required to obtain definitive conclusions.

In conclusion, quantitative detection of PAX1 methylation exhibited good diagnostic value in differentiating HSIL from CSCC in cervical tissues, while the efficiency of LMX1A methylation as a diagnostic tool requires further investigation.

\section{Acknowledgements}

The present study was supported by the National $\mathrm{Wu}$ Jieping Foundation for Clinical Scientific Research (grant no. 320.6750.13152) and the Project of Minhang Central Hospital (grant no. 2016MHJC06).

\section{References}

1. Divine LM and Huh WK: Tertiary prevention of cervical cancer. Clin Obstet Gynecol 57: 316-324, 2014.

2. Vizcaino AP, Moreno V, Bosch FX, Muñoz N, Barros-Dios XM Borras $J$ and Parkin DM: International trends in incidence of cervical cancer: II. Squamous-cell carcinoma. Int J Cancer 86: 429-435, 2000.

3. Vizcaino AP, Moreno V, Bosch FX, Muñoz N, Barros-Dios XM and Parkin DM: International trends in the incidence of cervical cancer: I. Adenocarcinoma and adenosquamous cell carcinomas. Int J Cancer 75: 536-545, 1998.

4. Li J, Kang LN and Qiao YL: Review of the cervical cancer disease burden in mainland China. Asian Pac J Cancer Prev 12: 1149-1153, 2011.

5. Burd EM: Human papillomavirus and cervical cancer. Clin Microbiol Rev 16: 1-17, 2003.

6. Kumar V, Abbas AK, Fausto N and Mitchell RN: Robbins Basic Pathology. Saunders Elsevier, Dublin, 2007.

7. Waxman AG, Chelmow D, Darragh TM, Lawson $\mathrm{H}$ and Moscicki AB: Revised terminology for cervical histopathology and its implications for management of high-grade squamous intraepithelial lesions of the cervix. Obstet Gynecol 120: 1465-1471, 2012

8. Agorastos T, Miliaras D, Lambropoulos AF, Chrisafi S, Kotsis A, Manthos A and Bontis J: Detection and typing of human papillomavirus DNA in uterine cervices with coexistent grade I and grade III intraepithelial neoplasia: Biologic progression or independent lesions? Eur J Obstet Gynecol Reprod Biol 121: 99-103, 2005.

9. Leda G, Akila NV, Carlos AP, William PT and Sharmila M: Cervical Cancer. http://www.cancernetwork.com/cancermanagement/cervical. Accessed Nov 01, 2015.

10. Jin B, Li Y and Robertson KD: DNA methylation: Superior or subordinate in the epigenetic hierarchy? Genes Cancer 2: 607-617, 2011.

11. Lee JY and Soong SJ: Cancer mortality in the South, 1950 to 1980. South Med J 83: 185-190, 1990.

12. Joshi S, Kulkarni V, Darak T, Mahajan U, Srivastava Y, Gupta S, Krishnan S, Mandolkar M and Bharti AC: Cervical cancer screening and treatment of cervical intraepithelial neoplasia in female sex workers using 'screen and treat' approach. Int J Womens Health 7: 477-483, 2015.

13. Pak SC, Martens M, Bekkers R, Crandon AJ, Land R, Nicklin JL, Perrin LC and Obermair A: Pap smear screening history of women with squamous cell carcinoma and adenocarcinoma of the cervix. Aust N Z J Obstet Gynaecol 47: 504-507, 2007.

14. Geldenhuys L and Murray ML: Sensitivity and specificity of the Pap smear for glandular lesions of the cervix and endometrium. Acta Cytol 51: 47-50, 2007.
15. Nanda K, McCrory DC, Myers ER, Bastian LA, Hasselblad V, Hickey JD and Matchar DB: Accuracy of the Papanicolaou test in screening for and follow-up of cervical cytologic abnormalities: A systematic review. Ann Intern Med 132: 810-819, 2000.

16. Lazcano-Ponce E, Alonso P, Ruiz-Moreno JA and Hernández-Avila M: Recommendations for cervical cancer screening programs in developing countries. The need for equity and technological development. Salud Publica Mex 45 (Suppl 3): S449-S462, 2003.

17. Nuovo J, Melnikow J and Howell LP: New tests for cervical cancer screening. Am Fam Physician 64: 780-786, 2001.

18. Flores-Miramontes MG, Torres-Reyes LA, Alvarado-Ruíz L, Romero-Martínez SA, Ramírez-Rodríguez V, Balderas-Peña LM, Vallejo-Ruíz $\mathrm{V}$, Piña-Sánchez $\mathrm{P}$, Cortés-Gutiérrez EI, Jave-Suárez LF and Aguilar-Lemarroy A: Human papillomavirus genotyping by linear array and next-generation Sequencing in cervical samples from Western Mexico. Virol J 12: 161, 2015.

19. Othman N and Othman NH: Detection of human papillomavirus DNA in routine cervical scraping samples: Use for a national cervical cancer screening program in a developing nation. Asian Pac J Cancer Prev 15: 2245-2249, 2014.

20. Natter C, Polterauer S, Rahhal-Schupp J, Cacsire Castillo-Tong D, Pils S, Speiser P, Zeillinger R, Heinze G and Grimm C: Association of TAP gene polymorphisms and risk of cervical intraepithelial neoplasia. Dis Markers 35: 79-84, 2013.

21. Cuzick J, Clavel C, Petry KU, Meijer CJ, Hoyer H, Ratnam S, Szarewski A, Birembaut P, Kulasingam S, Sasieni P and Iftner T: Overview of the European and North American studies on HPV testing in primary cervical cancer screening. Int J Cancer 119: 1095-1101, 2006.

22. Whitlock EP, Vesco KK, Eder M, Lin JS, Senger CA and Burda BU: Liquid-based cytology and human papillomavirus testing to screen for cervical cancer: A systematic review for the U.S. Preventive Services Task Force. Ann Intern Med 155: 687-697, W214-W215, 2011.

23. Loscalzo J and Handy DE: Epigenetic modifications: Basic mechanisms and role in cardiovascular disease (2013 Grover Conference series). Pulm Circ 4: 169-174, 2014.

24. Sakamoto A, Akiyama Y, Shimada S, Zhu WG, Yuasa Y and Tanaka S: DNA Methylation in the Exon 1 region and complex regulation of Twist 1 expression in gastric cancer cells. PLoS One 10: e0145630, 2015.

25. Fan H, Zhang H, Pascuzzi PE and Andrisani O: Hepatitis B virus $\mathrm{X}$ protein induces EpCAM expression via active DNA demethylation directed by RelA in complex with EZH2 and TET2. Oncogene 35: 715-726, 2016.

26. Schmid CA, Robinson MD, Scheifinger NA, Müller S, Cogliatti S, Tzankov A and Müller A: DUSP4 deficiency caused by promoter hypermethylation drives JNK signaling and tumor cell survival in diffuse large B cell lymphoma. J Exp Med 212: 775-792, 2015.

27. Sood S and Srinivasan R: Alterations in gene promoter methylation and transcript expression induced by cisplatin in comparison to 5-Azacytidine in HeLa and SiHa cervical cancer cell lines. Mol Cell Biochem 404: 181-191, 2015.

28. Kulis $\mathrm{M}$ and Esteller M: DNA methylation and cancer. Adv Genet 70: 27-56, 2010.

29. Chao TK, Ke FY, Liao YP, Wang HC, Yu CP and Lai HC: Triage of cervical cytological diagnoses of atypical squamous cells by DNA methylation of paired boxed gene 1 (PAX1). Diagn Cytopathol 41: 41-46, 2013

30. Lai HC, Lin YW, Huang RL, Chung MT, Wang HC, Liao YP, Su PH, Liu YL and Yu MH: Quantitative DNA methylation analysis detects cervical intraepithelial neoplasms type 3 and worse. Cancer 116: 4266-4274, 2010.

31. Lai HC, Lin YW, Huang TH, Yan P, Huang RL, Wang HC, Liu J, Chan MW, Chu TY, Sun CA, et al: Identification of novel DNA methylation markers in cervical cancer. Int J Cancer 123: 161-167, 2008.

32. Hammou JC, Bertino B, Blancheri A, Kon Man P and Patoz L: Pap test: Liquid-based-thin-layer. A new method: Results. Gynecol Obstet Fertil 31: 833-840, 2003 (In French).

33. WHO: An introduction to cervical intraepithelial neoplasia (CIN). http://screening.iarc.fr/colpochap.php?chap=2. Accessed Aug 15, 2015.

34. Elias JM, Margiotta M and Gaborc D: Sensitivity and detection efficiency of the peroxidase antiperoxidase (PAP), avidin-biotin peroxidase complex $(\mathrm{ABC})$, and peroxidase-labeled avidin-biotin (LAB) methods. Am J Clin Pathol 92: 62-67, 1989. 
35. Xu J, Xu L, Yang BH, Wang LF, Lin X and Tu H: Assessing methylation status of PAX1 in cervical scrapings, as a novel diagnostic and predictive biomarker, was closely related to screen cervical cancer. Int J Clin Exp Pathol 8: 1674-1681, 2015.

36. Wehr R and Gruss P: Pax and vertebrate development. Int J Dev Biol 40: 369-377, 1996.

37. Feiner N, Meyer A and Kuraku S: Evolution of the vertebrate Pax4/6 class of genes with focus on its novel member, the Pax 10 gene. Genome Biol Evol 6: 1635-1651, 2014.

38. Lang D, Powell SK, Plummer RS, Young KP and Ruggeri BA: PAX genes: Roles in development, pathophysiology, and cancer. Biochem Pharmacol 73: 1-14, 2007.

39. Lang D, Lu MM, Huang L, Engleka KA, Zhang M, Chu EY, Lipner S, Skoultchi A, Millar SE and Epstein JA: Pax3 functions at a nodal point in melanocyte stem cell differentiation. Nature 433: 884-887, 2005.

40. Sharma R, Sanchez-Ferras O and Bouchard M: Pax genes in renal development, disease and regeneration. Semin Cell Dev Biol 44: 97-106, 2015.

41. Hurtado A, Holmes KA, Geistlinger TR, Hutcheson IR, Nicholson RI, Brown M, Jiang J, Howat WJ, Ali S and Carroll JS Regulation of ERBB2 by oestrogen receptor-PAX2 determines response to tamoxifen. Nature 456: 663-666, 2008.

42. Galili N, Davis RJ, Fredericks WJ, Mukhopadhyay S, Rauscher FJ III, Emanuel BS, Rovera G and Barr FG: Fusion of a fork head domain gene to PAX3 in the solid tumour alveolar rhabdomyosarcoma. Nat Genet 5: 230-235, 1993.

43. Bennicelli JL, Advani S, Schäfer BW and Barr FG: PAX3 and PAX7 exhibit conserved cis-acting transcription repression domains and utilize a common gain of function mechanism in alveolar rhabdomyosarcoma. Oncogene 18: 4348-4356, 1999.

44. Liu W, Li X, Chu ES, Go MY, Xu L, Zhao G, Li L, Dai N, Si J, Tao Q, et al: Paired box gene 5 is a novel tumor suppressor in hepatocellular carcinoma through interaction with $\mathrm{p} 53$ signaling pathway. Hepatology 53: 843-853, 2011.

45. McGaughran JM, Oates A, Donnai D, Read AP and Tassabehji M Mutations in PAX1 may be associated with Klippel-Feil syndrome. Eur J Hum Genet 11: 468-474, 2003.

46. Bannykh SI, Emery SC, Gerber JK, Jones KL, Benirschke K and Masliah E: Aberrant Pax1 and Pax9 expression in Jarcho-Levin syndrome: Report of two Caucasian siblings and literature review. Am J Med Genet A 120A: 241-246, 2003.

47. Schnittger S, Rao VV, Deutsch U, Gruss P, Balling R and Hansmann I: Pax1, a member of the paired box-containing class of developmental control genes, is mapped to human chromosome 20 p11.2 by in situ hybridization (ISH and FISH). Genomics 14: 740-744, 1992.
48. Zhang Y, Chen FQ, Sun YH, Zhou SY, Li TY and Chen R: Effects of DNMT1 silencing on malignant phenotype and methylated gene expression in cervical cancer cells. J Exp Clin Cancer Res 30: 98, 2011.

49. Huang TH, Lai HC, Liu HW, Lin CJ, Wang KH, Ding DC and Chu TY: Quantitative analysis of methylation status of the PAX1 gene for detection of cervical cancer. Int J Gynecol Cancer 20: 513-519, 2010.

50. Chen W, Yang HJ, Xu J and Zhu HP: Quantitative analysis of LMX1A and PAX1 gene methylation in cervical cancer and cervical intraepithelial neoplasia. China Oncol 25: 19-24, 2015.

51. Kan YY, Liou YL, Wang HJ, Chen CY, Sung LC, Chang CF and Liao CI: PAX1 methylation as a potential biomarker for cervical cancer screening. Int J Gynecol Cancer 24: 928-934, 2014.

52. Lai HC, Ou YC, Chen TC, Huang HJ, Cheng YM, Chen $\mathrm{CH}$, Chu TY, Hsu ST, Liu CB, Hung YC, et al: PAX1/SOX1 DNA methylation and cervical neoplasia detection: A Taiwanese Gynecologic Oncology Group (TGOG) study. Cancer Med 3: 1062-1074, 2014

53. Lim EH, Ng SL, Li JL, Chang AR, Ng J, Ilancheran A, Low J, Quek SC and Tay EH: Cervical dysplasia: Assessing methylation status (Methylight) of CCNA1, DAPK1, HS3ST2, PAX1 and TFPI2 to improve diagnostic accuracy. Gynecol Oncol 119: 225-231, 2010

54. German MS, Wang J, Fernald AA, Espinosa R III, Le Beau MM and Bell GI: Localization of the genes encoding two transcription factors, LMX1 and CDX3, regulating insulin gene expression to human chromosomes 1 and 13. Genomics 24: 403-404, 1994

55. Dong W, Feng L, Xie Y, Zhang H and Wu Y: Hypermethylationmediated reduction of LMX1A expression in gastric cancer. Cancer Sci 102: 361-366, 2011.

56. Zhao Y, Guo S, Sun J, Huang Z, Zhu T, Zhang H, Gu J, He Y, Wang W, Ma K, et al: Methylcap-seq reveals novel DNA methylation markers for the diagnosis and recurrence prediction of bladder cancer in a Chinese population. PLoS One 7: e35175, 2012.

57. Su HY, Lai HC, Lin YW, Chou YC, Liu CY and Yu MH: An epigenetic marker panel for screening and prognostic prediction of ovarian cancer. Int J Cancer 124: 387-393, 2009.

58. Hagihara A, Miyamoto K, Furuta J, Hiraoka N, Wakazono K, Seki S, Fukushima S, Tsao MS, Sugimura T and Ushijima T: Identification of $275^{\prime} \mathrm{CpG}$ islands aberrantly methylated and 13 genes silenced in human pancreatic cancers. Oncogene 23: 8705-8710, 2004. 